https://doi.org/10.48009/2_iis_2009_40-47

\title{
A STUDY OF ERP SUCCESS FROM 2003 TO 2006 AS VIEWED BY TOP FINANCIAL EXECUTIVES
}

\author{
Alan R. Peslak, Penn State University, arp14@psu.edu
}

\begin{abstract}
The issue of success or failure of enterprise resource planning (ERP) systems has been under discussion for many years. This manuscript reviews the current status of ERP implementation success. In addition, it reviews progress made over the last several years on ERP. Variables that influence financial executive views on ERP success over time are explored. In general, ERP projects are viewed as moderately successful in 2006, a view that has not changed significantly since 2003. Areas that currently correlate with ERP success include on-budget performance and limited modifications. These influences have changed somewhat since 2003.
\end{abstract}

Keywords: enterprise resource planning, ERP, information systems, information technology, software modifications, budget, cost performance

\section{INTRODUCTION}

One of the most major software implementations in business organizations in the past decade has been enterprise resource planning systems. Large organizations were the first to implement these integrated systems and reap the potential savings. But now small and medium sized businesses are implementing as well. The key parts of an enterprise resource planning system are integrated modules that allow business process that cross business functional areas; one large real-time database that allows for a single entry and repository for information across business functions; and seamless business transactions across business functions (Miller, 2003). Generally, they consist of a series of functional modules that are integrated through standard business processes and include all the data and information about vendors, customers, employees, and products. The common modules include accounting, sales and marketing, logistics, purchasing, manufacturing, human resources, and inventory. McAdam and Galloway (2005) note that ERP systems allow "standardising business processes, ensuring integrity of data, and removing the number, complexity, and expense surrounding old independent legacy systems." McAdam and Galloway (2005) suggest that ERP systems can play an "increasingly important role in sustaining 'leading edge' competitiveness. The size of the ERP market is estimated at $\$ 12$ billion (Arc Advisory Group, 2003) to $\$ 30$ billion (King, 2005) sales and a market penetration estimated at $70 \%$ of the Fortune 1000 (Bingi, Sharma, and Godla, 1999). This hugely important implementation has had a spotty record of success according to some experts.

Barker and Frolick (2003) suggest that 50\% of ERP implementations are failures. Hong and Kim (2002) estimate a 75\% "unsuccessful" rate. And Scott and Vessey (2002) and Martin (1998) estimate failure as high as $90 \%$.

Hunton, McEwen, and Weir (2002) noted the "paucity of empirical research examining the impact of ERP system implementations on firm performance". A review of the actual financial performance of firms that invested in ERP implementations was also studied by another group of researchers who looked at actual financial data. Hitt, Wu, and Zhou (2002) found that "firms that invest in ERP tend to show a higher performance across a wide variety of financial metrics". Our study reviews ERP success from another perspective, the internal assessment by senior financial managers within a firm itself.

This study of top financial executives examines their views on their organizations' ERP systems implementation. A survey developed and distributed by Financial Executives International explores top financial executive views on the relative success of their ERP implementation. It also explores various influences that affect how this implementation is viewed. Multiple regression analysis is used to explore the relationship between these variables and perceived ERP success. The results and implications of these analyses are discussed.

\section{Hypothesis development}

Many of the studies which have suggested high ERP failure rates have been performed by consulting and industry organizations. As noted, failure rates range from 50\% (Barker and Frolick, 2003) to 90\% (Scott and Vessey, 2002). With such a large variation in estimates of ERP project success, an independent 
estimate of ERP success rates is in order. Also, with such a large market penetration of $70 \%$ of Fortune 500 (Bingi, Sharla, and Godla, 1999), it does not seem that such high failure rates are possible. Since so much money and effort are being expended on ERP systems and with their high penetration rate, we propose that the high failure rates may be exaggerated. As a result, we propose hypothesis one.

H1. Enterprise resource planning systems will generally be viewed as successful by major organizations.

Based on past literature, there does not seem to be any correlation between the year of the study and specific success rates (Barker and Frolick (2003) Hong and Kim (2002) Scott and Vessey (2002) and Martin (1998)). Therefore, hypothesis two is proposed.

H2. Rating of Enterprise resource planning systems success did not significantly change over the last several years.

It is hypothesized that there are variables that affect the overall perception of success in ERP implementations. As an example, Bryde and Robinson (2005) found a high emphasis on cost and time performance in projects.

H3. Significant variables will be found that affect how ERP success is viewed in major organizations.

As noted, there does not appear to be a relationship between years on ERP success rates. It is therefore suggested that the variables affecting how success is viewed are not anticipated to change. It is also suggested that underlying variables themselves will also not have changed over time.

H4. There was little or no change in significant variables affecting ERP success in major organizations over the last several years.

H5. There will be little or no change in ERP descriptive variables over the past several years.

\section{Methodology}

In order to test these hypotheses, specific major corporate data were required. We found a rich data set that was available from Financial Executives International. Financial Executives International is "the preeminent association for CFOs and other senior finance executives." It has ... CFOs, VPs of Finance, Treasurers, Controllers, Tax Executives,
Academics, Audit Committee members [in] companies large and small, public and private, crossindustry. (FEI, 2006 a) The FEI, each year, commissions a large scale study of "technology issues for Financial Executives". The survey instructions follow.

"FEI's Committee on Finance \& information Technology (CFIT) and Financial Executives Research Foundation (FERF), in partnership with Computer Sciences Corporation (CSC), are conducting the eighth annual survey of Technology Issues for Financial Executives. This initiative explores and reports on information technology from the perspective of the financial executive. Last year we set another record for survey participation with nearly 800 responses, continuing our unbroken streak of year-over-year increases since the survey's inception. As part of this year's effort, we are targeting another significant increase in response volume so that we can expand the resulting publication to include more analyses by industry and company size. In turn, this will allow you to better compare and benchmark your company. If you have responded to previous surveys, we offer our sincere thanks and request your continued support. If you did not participate previously, we strongly encourage you to do so. This year's questionnaire incorporates feedback and suggestions from last year's respondents and is organized into five sections:

I. Demographics

II. Top Financial Management Issues

III. Information Technology Strategies

IV. Technology Applications

V. Managing the IT Function

.$"$ (FEI, 2006 b)

As a part of this study, specific information was obtained from top financial executives on ERP implementation. These questions and responses were sufficiently detailed and pertinent to our hypotheses to serve as the bases for testing this study's hypotheses. The main advantage is the large data set and the independent collection from a private membership trade group. All data has been collected and furnished by the Financial Executives International and remains their property. Use for academic and research purposes was obtained by the author. The author wishes to sincerely thank the organization for their cooperation

\section{Demographics of participants}

Overall, in the 2006 survey there were 183 usable responses from major corporations who completed implementation of an enterprise solution. In 2003 
there were 215 usable responses. The demographics

of the group follow.

Table 1. Level in Organization of Respondent

\begin{tabular}{|c|c|c|c|c|}
\hline & & 2006 & & 2003 \\
\hline & Frequency & Percent & Frequency & Perce \\
\hline Corporate & 159 & 86.9 & 176 & \\
\hline Group of Sector & 6 & 3.3 & 5 & \\
\hline Division, wholly owned subsidiary, or operating unit & 18 & 9.8 & 34 & \\
\hline Total & 183 & 100.0 & 215 & \\
\hline
\end{tabular}

In 2006 , nearly $87 \%$ of the respondents were from the Corporate Level as shown in table 1. The sample reflects the strong executive position that most of the respondents held. There was somewhat of an increase in corporate executive responses (as a percentage) between 2003 and 2006. This study thus reflects top executive views on the related technology. The remaining participants were at the Group or Division/Unit level. Table 2 reflects the location of the participants. Though Financial Executives International recently became an international organization, its international membership opened only in 2000 and the organization retains a heavy US membership. As a result, $84 \%$ of the respondents are from the US and another $10 \%$ are from Canada. There is a North American bias to the results. There is little change in this from 2003.

Table 2. Country Where Respondent is Based

\begin{tabular}{|l|l|l|l|l|}
\hline & & 2006 & & 2003 \\
\hline & Frequency & Valid Percent & Frequency & Valid Percent \\
\hline Canada & 18 & 9.8 & 29 & 13.6 \\
\hline Europe & 6 & 3.3 & 4 & 1.9 \\
\hline United States 157 & 85.3 & 178 & 83.2 \\
\hline Other & 3 & 1.6 & 3 & 1.4 \\
\hline Total & 184 & 100.0 & 214 & 100.0 \\
\hline
\end{tabular}

Table 3 reflects the size distribution of the organizations. In general, the organizations are large with $69 \%$ over $\$ 100$ million in sales. The largest respondents were in the \$100-499 million

Table 3.Size of Organization in Sales Dollars

\begin{tabular}{|l|l|l|l|l||}
\hline & & 2006 & & 2003 \\
\hline & Frequency & Percent & Frequency & Percent \\
\hline Less than 100m & 58 & 31.5 & 73 & 34.0 \\
\hline $100-499$ & 65 & 35.3 & 78 & 36.3 \\
\hline $500-999$ & 17 & 9.2 & 21 & 9.8 \\
\hline $1-5 B$ & 32 & 17.4 & 30 & 14.0 \\
\hline More than 5 & 12 & 6.5 & 13 & 6.0 \\
\hline Total & 184 & 100.0 & 215 & 100.0 \\
\hline
\end{tabular}

The overwhelming majority of respondents were senior executives $(72 \%-81 \%)$. There is a strong representation at the top levels of management. sales category but there were still 44 respondents with sales greater than $\$ 1$ billion. These data sets are relatively similar between 2006 and 2003. 
Table 4. Senior Executive Status in Organization

\begin{tabular}{|c|c|c|c|c|}
\hline & & 2006 & & 2003 \\
\hline & Frequency & yPercen & Frequency & Percent \\
\hline Senior & 132 & 72.9 & 173 & 80.5 \\
\hline Not Senior & 49 & 27.1 & 42 & 19.5 \\
\hline Total & 181 & 100.0 & 215 & 100.0 \\
\hline
\end{tabular}

\section{Questionnaire}

The overall questionnaire included 44 questions in the noted categories but sub-questions and ranked responses raised the overall individual data points to more than 220. From this overall report a small subsection were used to analyze the relevant hypotheses. Selected responses from the Demographics section were included as well as the specific ERP responses from the Technology Applications section.

The key question for hypotheses one and two is question $8 \mathrm{~h}$ in section IV.

10h. How would you rate the project?

(Mark only one.)

Highly successful

Moderately successful

Neutral

Moderately problematic

Failure

This is the overall measure of success as perceived by the top financial executives. The demographic questions are noted in Section I. This is followed by the specific enterprise questions in section IV. First, there is a qualifying question that determines whether an enterprise-wide solution is being implemented. If the answer is no, then a follow-up is used to determine if the reason one is not being implemented is because they "have already implemented an enterprise-wide solution". These were the responses used. If this question is answered in the affirmative then the remaining ERP questions were answered.

\section{Analysis of Demographics}

The respondent group found diversity in many of the demographic categories. In order to determine whether those variances affected the overall rating on the enterprise projects, a series of ANOVA were performed. The significance results of these analyses are shown in table 5. An ANOVA analysis found no significant difference in 2006 between success rates based on organization base (location), senior executive or not, and size. The current data do not support Buonanno et al. (2005) who saw company size as a significant variable in successful ERP adoption. As a result of this ANOVA analyses we can assume that size, seniority, and location did not have an impact on the organization ERP success and are excluded from further consideration.

Table 5. Significance of ANOVA variance between groups

\begin{tabular}{|l|l|l|}
\hline & $\mathrm{p}$ value -2003 & 2006 \\
\hline Organization Base & .289 & .374 \\
\hline Senior Executive & .253 & .401 \\
\hline Size & .004 & .423 \\
\hline
\end{tabular}

\section{RESULTS}

The data set was analyzed via SPSS 15.0 using multiple regression analysis and other statistical methods. Each of the proposed hypotheses was studied.
H1. Enterprise resource planning systems will generally be viewed as successful by major organizations.

This hypothesis was tested based on the scalar question Section IV, 8h (2003) and 10h (2006).

On a scale of 1 to 5 How would you rate the project?

(Mark only one.) 
Highly successful

Moderately successful

Neutral

\author{
Moderately problematic \\ Failure
}

Table 6. Rate Group Statistics

\begin{tabular}{|l|l|l|l|l|l|}
\hline & year & $\mathrm{N}$ & Mean & Std. Deviation & Std. Error Mean \\
\hline \multirow{2}{*}{ Rate } & 2003.00 & 209 & 2.0813 & 1.01341 & .07010 \\
\cline { 2 - 6 } & 2006.00 & 166 & 1.9639 & .90715 & .07041 \\
\hline
\end{tabular}

The mean value for this question for 2006 was 1.96 and 2.08 for 2003 (table 6). Both of these are nearest to 2, moderately successful. Using techniques like Lawson (2004) results of onesample t-tests were performed using a null hypothesis that the population mean was 3.0 ("Neutral"). As a result of the t-test, the null hypothesis is rejected. Significance is at $p<$ .001. This significance test was performed for both 2003 and 2006. Enterprise resource planning systems implementations are generally viewed as successful by major organizations.

H2. Rating of Enterprise resource planning systems success did not significantly change over the last several years.

An independent samples test was performed to determine if there was a significant difference between 2003 and 2006. Though there was some improvement in rating between 2003 and 2006, the level of significance is only .244. This is not significant even at a modest social science rate used of $\mathrm{p}<.10$. There was no significant difference between 2003 and 2006 level of ERP success. Rate of return improved between 2003 and 2006 but the rate of change was not statistically significant.

H3. Significant variables will be found that affect how ERP success is viewed in major organizations.

Multiple regression analysis was used to determine whether and to what extent selected variables influenced the financial executives' view of the overall project. A series of variables were studied to determine their correlation with financial executives' views on overall ERP project success. These variables were: percentage of work done by in-house IS staff, percentage of work done by in-house users, percentage of work performed by external consultants, percentage of work done by ERP vendors, on-time project performance, on-budget project performance, and extent of modifications to the system. Of these variables, in 2006, the number of modifications made to the ERP system was significant at $\mathrm{p}<.01$ and on-budget performance was significant at $\mathrm{p}<.05$.

In 2003 on-time performance, on-budget performance, and number of modifications all significantly correlated with overall project rating at $\mathrm{p}<.01$.

Hypothesis three was supported. There were variables that influenced overall project success.

H4. There was little or no change in significant variables affecting ERP success in major organizations over the last several years.

There was a change in significant variables influencing overall project success rating. Ontime performance no longer correlates significantly with rate of success. Also on-costbudget performance now only correlates at $\mathrm{p}<.051$. Hypothesis four was rejected. There were changes to influences between 2003 and 2006.

H5. There will be little or no change in ERP descriptive variables over the past several years. A review of the variables potentially influencing separately showed a significant mix change in personnel working on ERP implementations between 2003 and 2006 (tables 7, 8 and 9). Work done by ERP vendors was significantly up. Other variables including time, budget, and modifications did not show significant change between 2003 and 2006. Data were scrubbed to eliminate firms whose total ERP personnel mix did not add to 100 . 
Table 7 Variables codes

\begin{tabular}{|l|l|}
\hline code & Full \\
\hline CinIS & percentage of work done by in-house IS staff \\
\hline CinUS & percentage of work done by in-house users \\
\hline Ccons & percentage of work performed by external consultants \\
\hline Cvend & percentage of work done by ERP vendors \\
\hline time & on-time project performance Percentage on time \\
\hline bud & on-budget project performance Percentage on budget \\
\hline mod & extent of modifications to the system Percentage of modifications \\
\hline
\end{tabular}

Table 8. Variables Mix Means Report

\begin{tabular}{|l|l|l|l|l|l|}
\hline \multirow{2}{*}{ CinIS } & year & $\mathrm{N}$ & Mean & Std. Deviation & Std. Error Mean \\
& 2003 & 204 & 33.89216 & 21.07454 & 1.475513 \\
\cline { 2 - 6 } & 2006 & 158 & 31.73418 & 18.57655 & 1.477871 \\
\hline CinUS & 2003 & 204 & 32.12255 & 20.55558 & 1.439178 \\
\cline { 2 - 6 } & 2006 & 158 & 33.23418 & 19.12752 & 1.521704 \\
\hline Ccons & 2003 & 204 & 27.67647 & 21.404 & 1.49858 \\
\cline { 2 - 6 } & 2006 & 158 & 25.93038 & 19.656 & 1.563747 \\
\hline Cvend & 2003 & 215 & 6.308824 & 9.883445 & 0.69198 \\
\cline { 2 - 6 } & 2006 & 90 & 9.101266 & 14.71521 & 1.170679 \\
\hline \multirow{3}{*}{ time } & 2003 & 202 & 3.6337 & 0.90022 & 0.06334 \\
\cline { 2 - 6 } & 2006 & 161 & 3.5404 & 0.85873 & 0.06768 \\
\hline \multirow{3}{*}{ bud } & 2003 & 203 & 3.7389 & 0.818 & 0.05741 \\
\cline { 2 - 6 } & 2006 & 152 & 3.6842 & 0.81721 & 0.06628 \\
\hline mod & 2003 & 209 & 2.4163 & 0.93743 & 0.06484 \\
\cline { 2 - 6 } & 2006 & 163 & 2.5644 & 0.90292 & 0.07072 \\
\hline
\end{tabular}

Table 9. Independent Samples Test t-test for Equality of Means

\begin{tabular}{|l|l|l|}
\hline & & Sig. (2-tailed) \\
\hline & & Lower \\
\hline CinIS & Equal variances assumed & .31 \\
\hline & Equal variances not assumed & .302 \\
\hline CinUS & Equal variances assumed & .599 \\
\hline & Equal variances not assumed & .596 \\
\hline Ccons & Equal variances assumed & .426 \\
\hline & Equal variances not assumed & .421 \\
\hline Cvend & Equal variances assumed & .032 \\
\hline & Equal variances not assumed & .041 \\
\hline time & Equal variances assumed & .317 \\
\hline & Equal variances not assumed & .315 \\
\hline Bud & Equal variances assumed & .533 \\
\hline & Equal variances not assumed & .533 \\
\hline Mod & Equal variances assumed & .125 \\
\hline & Equal variances not assumed & .123 \\
\hline
\end{tabular}




\section{Discussion and Conclusion}

As with any research there are limitations with this study. The main limitation is use of secondary data to uncover the relationships between certain variables and ERP success. On the other hand, this is a broad-based study by an independent organization with strong executive participation. Researchers can duplicate this study with primary research perhaps with indepth interviews to further understand the initial finding.

The good news is that those who have reported worst case scenarios appear to be wrong. Generally, top financial executives in a wide cross-section of major industries report moderate success with their enterprise resource planning implementation. This assessment has not changed significantly between 2003 and 2006. In 2006, the rating was 1.96 (1=highly successful and $2=$ moderately successful). This rating is significantly different from a neutral position. The implication for practitioners is that ERP systems when properly implemented can provide good returns for an organization. Organizations can confidently move forward knowing that generally firms do get return from their ERP investment. Another way of viewing the 2006 data is that $82 \%$ of the respondent reported moderate or high success. Only six percent saw the project as problematic and only two percent saw the project as a failure. Again, this suggests a positive environment for future ERP implementations and enhancements.

Important implications for practitioners are evident in the limited regression study performed here. Modifications to this complex software, known as enterprise resource planning, result in lower success rates. This finding was apparent in 2003 but appears even more important in 2006. Extreme care must be taken when making modifications to an ERP system. Success has been more difficult with higher modifications. Also important is attention to budget. Those that exceeded cost budgets showed lower success rates. This was true for both 2003 and 2006 . Project time overages were a factor in overall rating of the project in 2003 but not in 2006. Perhaps this is related to better understanding of scheduling or more patience on the part of executives. It does not emerge as a significant variable influencing rating in 2006.
Finally, it is interesting to note that the mix of resources working on ERP implementations as the reliance on vendors has significantly increased. This bodes well for the services arm of ERP software firms.

Overall, this study extends the practical study of ERP success and its influencing variables. Researchers can use the results as a springboard for further analysis and study. Practitioners should be able to use these finding to improve their operations.

\section{REFERENCES}

1. ARC Advisory Group. (2003). ERP market opportunities change while remaining strong overall at $\$ 8.9$ billion, Available http://www.arcweb.com/Community/ar cnews/arcnews.as $\mathrm{p}$ ? ID $=328$.

2. Barker, T. and M. Frolick (2003). ERP implementation failure: a case study, Information Systems Management, 20(4), 43-49.

3. Bingi, P., Sharma, M. and Godla, J. (1999). Critical issues affecting an ERP implementation, Information Systems Management, 16(3), 7-14.

4. Bryde, D. and Robinson, L. (2005). Client versus contractor perspectives on project success criteria, International Journal of Project Management, 23(8), 622-629

5. Buonanno, G., Faverio, P., Pigni, F., Ravarini, A., Sciuto, D., and Tagliavini, M. (2005), Factors affecting ERP system adoption: A comparative analysis between SMEs and large companies, Journal of Enterprise Information Management. 18(4), 384426.

6. FEI (2006 a), About FEI, Available http://www.fei.org/about/us.cfm

7. FEI (2006 b), 2006 FEI/CSC Study Technology Issues for Financial Executives, Financial Executives International. 
8. Hitt, L., Wu, D., and Zhou, X. (2002). Investment in Enterprise Resource Planning: Business Impact and Productivity Measures, Journal of Management Information Systems. 19(1), 71-98.

9. Hong, K and Y. Kim (2002). The critical success factors for ERP implementation: an organizational fit perspective, Information and Management, 40(1), 25-40.

10. Hunton, J., McEwen, R. and Weir, B. (2002). The reaction of financial analysts to Enterprise Resource Planning (ERP) implementation plans., Journal of Information Systems. 16(1), 31-40.

11. King, W. (2005). Ensuring ERP implementation success, Information Systems Management, 22(3), 83-4.

12. Lawson, R. (2004). Is Classroom cheating related to business students' propensity to cheat in the "real world"?, Journal of Business Ethics, 49, 189-199.

13. Martin, M. (1998). An electronics firm will save big money by replacing six people with one and lose all the paperwork, using enterprise resource planning software. But not every company has been so lucky, Fortune, 137(2), 149-51.

14. Miller, B. (2003), What is ERP?, CIO, Available

http://www2.cio.com/analyst/report200 $\underline{\text { 3.html . }}$

15. McAdam, R. and Galloway (2005). Enterprise resource planning and organizational innovation: a management perspective, Industrial Management + Data Systems, 105(3), 280-290.

16. Scott, J. and Vessey, I. (2002). Managing risks in enterprise implementations, Communications of the ACM, 45(4), 74-81. 